\title{
Production of mahogany particleboards using branches and wood residues
}

\author{
Produção de paineis de partículas usando galhos e \\ resíduos da madeira de mogno
}

\author{
Vitor Uemura da Silva \\ Vinicius Borges de Moura Aquino \\ Heloiza Candeia Ruthes \\ André Luis Christoforo \\ Francisco Antonio Rocco Lahr
}

\begin{abstract}

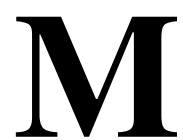

ahogany (Swietenia macrophylla King) is one of the most valuable wood species found in the American Continent. This study is an evaluation of the production of particleboards using wood residues from the branches and trunk of a mahogany tree. It was designed to test the feasibility of production and the mechanical and physical characteristics of the finished particleboards, as well as to compare the results with similar studies and the requirements of normative documents. The particles were generated from the trunk and branches of a mahogany tree separately and mixed in different proportions to test their influence on the final product. They were bonded using $12 \%$ polyurethane resin from renewable resources and pressed under $90^{\circ} \mathrm{C}$ and 3.5 MPa for 10 minutes. The specimens were prepared and tested according to the guidelines established by the NBR 14810 regarding the static bending, internal bond, stiffness and thickness swelling (24h) tests. The results indicated that there is no significant correlation between the trunk-branches proportion and the Modulus of Elasticity/Rupture values. The production of the particleboards using the residues is feasible and the results of most of the tests fitted the normative requirements, which means that with the refinement of the production process it is possible to have a good product that fully complies with the technical standards.
\end{abstract}

${ }^{1}$ Vitor Uemura da Silva 'University of São Paulo São Carlos - SP - Brasil ${ }^{2}$ Vinicius Borges de Moura Aquino
${ }^{2}$ Federal University of South Santana do Araguaia - PA - Brasil

${ }^{3}$ Heloiza Candeia Ruthes ${ }^{3}$ Federal University of São Carlos São Carlos - SP - Brasil

${ }^{4}$ André Luis Christoforo ${ }^{4}$ Federal University of São Carlos São Carlos - SP - Brasil

${ }^{5}$ Francisco Antonio Rocco Lahr ${ }^{5}$ University of São Paulo São Carlos - SP - Brasil

Recebido em 08/03/21 Aceito em 20/08/21

Keywords: Reutilization. Swietenia macrophylla. Solid residues. Wood-based products. Particleboard.

\section{Resumo}

A madeira de mogno (Swietenia macrophylla King) é uma das mais valiosas encontradas no Continente Americano. Esse trabalho visou avaliar a produção de painéis de partículas de resíduos dos galhos e troncos dessa espécie. Foram avaliados a viabilidade de produção, as propriedades físicas e mecânicas e, além disso, foi realizada a comparação dos resultados com estudos similares e requisitos de normas. Os painéis foram fabricados a partir dos resíduos do tronco e dos galhos, de forma separada e misturados em diferentes proporções para testar sua influência no produto final. Foram aglomerados usando resina de poliuretano e prensados a $90^{\circ} \mathrm{C}$ e 3,5 $\mathrm{MPa}$ por 10 minutos. As amostras foram testadas para flexão estática, aderência interna, rigidez e inchamento (24 h), de acordo com as recomendações da NBR 14810. Os resultados indicaram que não houve correlação significativa entre a proporção tronco-galhos e os valores de módulo de elasticidade/ruptura. A produção dos painéis foi considerada viável e os resultados da maioria dos testes atenderam aos requisitos normativos.

Palavras-chave: Reutilização. Swietenia macrophylla. Resíduos Sólidos. Produtos em madeira. Paineis de partículas.

SILVA, V. U. da; AQUINO, V. B. de M.; RUTHES, H. C.; CHRISTOFORO, A. L.; LAHR, F. A. R. Production of mahogany particleboards using branches and wood residues. Ambiente Construído, Porto Alegre, v. 22, n. 1, p. 191-199, jan./mar. 2022.

ISSN 1678-8621 Associação Nacional de Tecnologia do Ambiente Construído. http: //dx.doi.org/10.1590/s1678-86212022000100587 


\section{Introduction}

Mahogany (Swietenia macrophylla King) is one of the most valuable wood species found in the American Continent and in many sawmills. It occurs naturally over an area that comprises Central America, Venezuela, Colombia, Ecuador, Peru and Brazilian States of Acre, Amazonas, Rondônia, Mato Grosso and Pará with an average density of less than one specimen per hectare (GROGAN et al., 2008; LAMB, 1966), being one of the finest materials in furniture market due to its aesthetic and mechanical characteristics (RIZZINI, 1990).

High demand, high market prices and lack of surveillance contributed to developing a scenario of overexploitation that depleted many mahogany stocks (BLUNDELL; GULLISON, 2003; VERÍSSIMO et al., 1995), and the outcome was its listing on CITES (Convention on International Trade in Endangered Species of Wild Fauna and Flora) Appendix II in November 2002 (BLUNDELL, 2004).

Even when all measurements to comply with extraction laws are taken, Brazilian wood sector still faces the problem of generating residues on large scales. According to the National Policy on Solid Residues (BRASIL, 2010), only $30 \%$ of a tree is properly transformed into sawn wood, which means that $70 \%$ of the material ends up as residue.

The final destination of such residues may vary (energy generation, animal bedding, kiln firing) and Rivela et al., (2006) demonstrated that particleboard production is more environmentally beneficial than energy generation. But, as shown by Gerwing, Johns and Vidal (1996) and Sasaki et al. (2016), in the north region of Brazil, many sawmills don't even have an active recycling program and their wastes are often discarded in natura or burnt without any commercial purpose.

The branches of a mahogany tree contribute to about $17 \%$ of its total biomass (ADINUGROHO; SIDIYASA, 2006), and they are often discarded as residue, but Bertolini et al. (2014) showed that these elements are also suitable for particleboard production.

Given the background of over-exploitation and waste generation and considering that recently a company got a FSC certificate to legally extract mahogany from Pará (FOREST..., 2016), this study comes as a way to enlighten the reader to the possibility of using mahogany sawmill residues in addition to the branches from pruning and limbing processes to produce high quality particleboards that could be used by furniture industry or in building construction, therefore minimizing environmental impact of the extraction chain and adding more value to mahogany's commercial cycle.

Also, it is important to highlight that, the use of an alternative resin such as castor oil polyurethane resin meet the cleaner requirement when compared to urea-formaldehyde and phenol-formaldehyde adhesives, using less energy on productive process and not release formalin gas along manufacture, toxic gas for human being (SILVA et al., 2014; FERRO et al., 2018; MACEDO et al., 2019; YANO et al., 2020).

\section{Materials and methods}

Firstly, it is worth to make clear that the mahogany tree used in this study was part of the University's flora. It was a young tree (about 20 years old) that fell down during a windstorm and the Wood and Timber Structures Laboratory (LaMEM) was given permission to use it for research purposes. The tree was limbed and cut into smaller pieces that were let dry until a $12 \%$ humidity level was reached (the branches were stored separately not to mix with the trunk wood).

Particles were generated using a cutting mill equipped with a separation sieve (Figure 1b) able to produce particle dimensions ranging from $0.6 \mathrm{~mm}$ to $5 \mathrm{~mm}$ diameter and they were stored in sealed containers to prevent contact with the external atmosphere.

Each particleboard was designed to have a nominal volume of $784 \mathrm{~cm}^{3}(28 \times 28 \times 1 \mathrm{~cm})$ and to be medium density according to the NBR 14810 (ABNT, 2018); the nominal density adopted as base for calculations was $725 \mathrm{~kg} / \mathrm{m}^{3}$, also there would be four different treatments varying the ratio of particles from the trunk and from the branches according to Table 1 .

A total of $507.5 \mathrm{~g}$ of wood particles (Figure 1a) was mixed with $60.9 \mathrm{~g}$ of the polyurethane resin $(12 \%$ of particles' dry weight) using an industrial mixer for 5 minutes (Figure 1d). The resin used was the castor oilbased bicomponent polyurethane resin with polyol $(1.2 \mathrm{~g} / \mathrm{cm})$ made from castor oil (Figure 1c) and was mixed in the 1:1 ratio (Polyol and Pre-Polymer) as done by similar previous studies (FERRO et al., 2014) which obtained good mechanical characteristics and an adequate gel.

192 Silva, V. U. da; Aquino, V. B. de M.; Ruthes, H. C.; Christoforo, A. L.; Lahr, F. A. R. 
Table 1 - Branch and trunk particle proportion for each treatment

\begin{tabular}{c|c|r}
\hline Treatment & Branches & Trunk \\
\hline T1 & $100 \%$ & $0 \%$ \\
T2 & $50 \%$ & $50 \%$ \\
T3 & $33 \%$ & $67 \%$ \\
T4 & $0 \%$ & $100 \%$ \\
\hline
\end{tabular}

Figure 1 - Wood particles (a); Cutting mill and sieves (b); Bicomponent resin (c); Mixing pan (d); Mold (e); Matress (f); Hydraulic press (g); and Finished particleboard

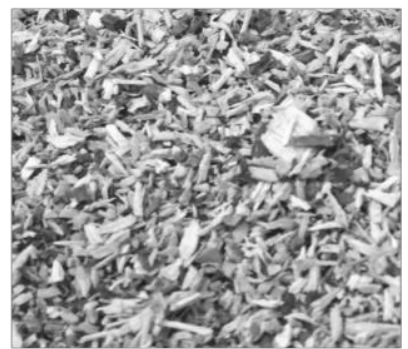

(a)

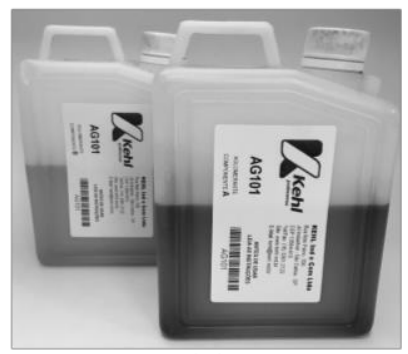

(c)

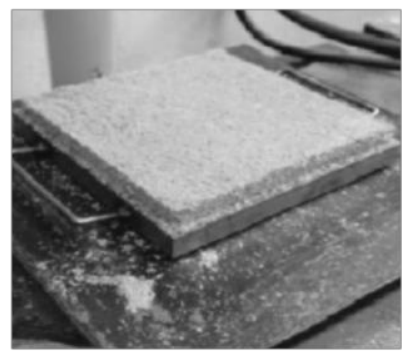

(f)

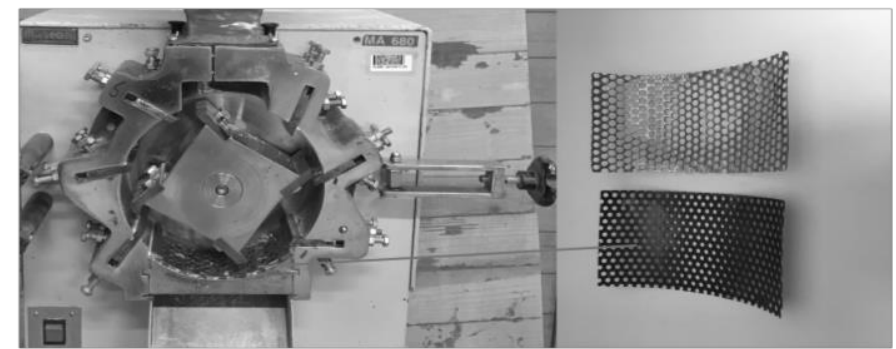

(b)

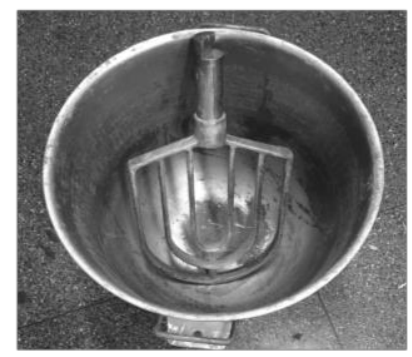

(d)

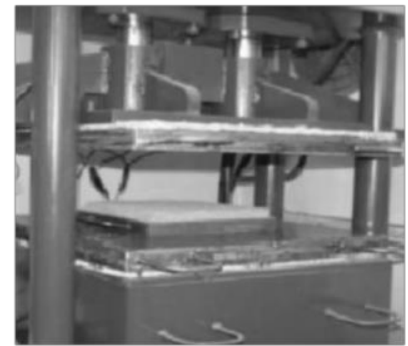

(g)

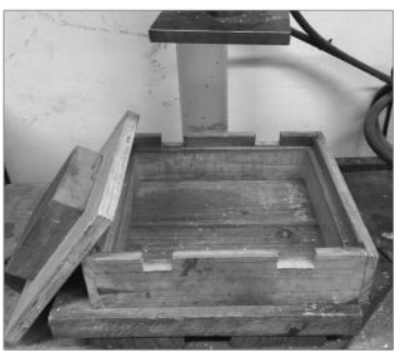

(e)

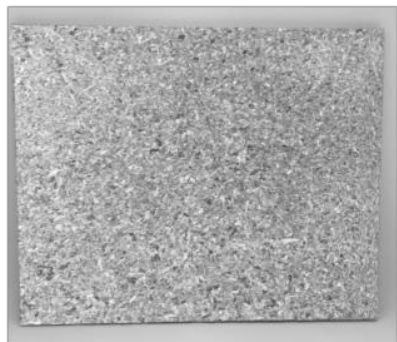

(h)

The particle-resin mix was put into a square mold (Figure 1e) and pre-pressed for 15 minutes at $1 \mathrm{MPa}$ and room temperature to form the mattress (Figure 1f), which then was taken to the hydraulic press under 3.5 $\mathrm{MPa}$ and $100{ }^{\circ} \mathrm{C}$ for 10 minutes (Figure $1 \mathrm{~g}$ ). Each treatment was repeated 4 times to produce a total of 16 particleboards that were stored for 72 hours until the complete cure of the resin (Figure 1h). Figure 1 below shows the production processes.

Each board was cut according to parameters stated in the normative document NBR 14810 (ABNT, 2018) that defines the setup and specimens' dimensions for the tests applied to grade the particleboard. The first action was to cut four $50 \times 250 \mathrm{~mm}$ specimens from each board to the static bending test; the specimens for the density, internal bond, face and edge screw-holding and thickness swelling ( 2 and 24 hours) tests have the same dimensions $(50 \times 50 \mathrm{~mm})$ and were cut from the bent specimen, from the region between the fractioned center and the tip of the piece. The specimen cut pattern and the quantities per test are shown in Figure 2 and Table 2 respectively.

Physical properties evaluated were density (d), thickness swelling after 2 hours (TS2) and after 24 hours (TS24). Mechanical properties evaluated were: 
(a) Modulus of elasticity (MOE);

(b) Modulus of rupture (MOR);

(c) Internal bond (IB);

(d) Face screw-holding (FSH); and

(e) Edge screw-holding (ESH).

The data collected from the tests was analysed to investigate the behaviour of the mechanical and physical properties of the particleboards as the percentage of wood from the branches was raised from $0 \%$ to $100 \%$ as described before. A Tukey test was applied with 5\% significance, and also a Bartlett and Anderson-Darling tests were used to check homogeneity and normality of the residuals from ANOVA in order to validate the Tukey test.

\section{Results and discussion}

Table 3 shows the mean values of the mechanical and physical characteristics obtained in the tests per treatment, as well as the respective variance coefficients (VC) of each one.

Figure 2 - Specimen cut pattern

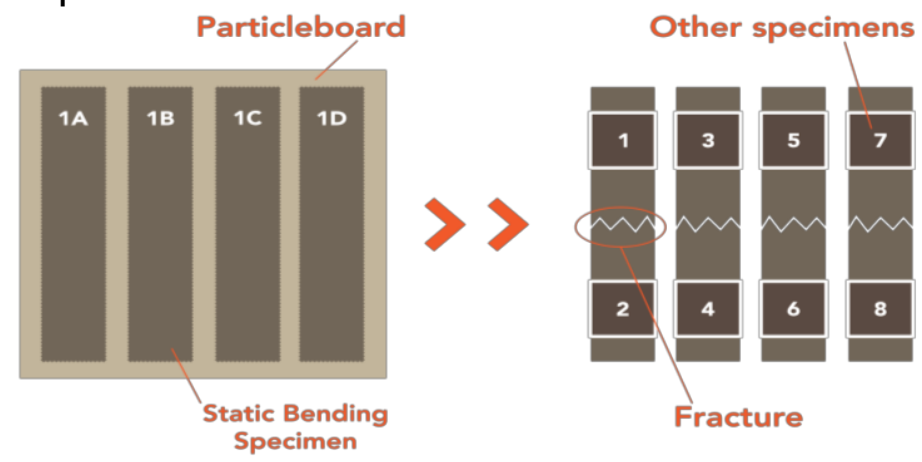

Table 2 - Quantities and dimensions of specimens per test

\begin{tabular}{l|c|c|c}
\hline \multicolumn{1}{c|}{ Test } & Standard & Number of Specimens & Dimensions \\
\hline Static Bending & & 16 & $250 \times 50 \mathrm{~mm}$ \\
Face screw-holding (FSH) & NBR & 16 & $50 \times 50 \mathrm{~mm}$ \\
Edge screw-holding (ESH) & 14810 & 16 & $50 \times 50 \mathrm{~mm}$ \\
Internal Bond (IB) & (ABNT, & 16 & $50 \times 50 \mathrm{~mm}$ \\
Density & $2018)$ & 16 & $50 \times 50 \mathrm{~mm}$ \\
Thickness Swelling (TS) - 2 and 24 hours & & 16 & $50 \times 50 \mathrm{~mm}$ \\
\hline
\end{tabular}

Table 3 - Results of physical and mechanical properties

\begin{tabular}{c|c|c|c|c}
\hline Treatment & $\begin{array}{c}\text { Density } \\
\left(\mathbf{g} / \mathbf{c m}^{\mathbf{3}}\right)\end{array}$ & $\begin{array}{c}\text { MOE } \\
(\mathbf{M P a})\end{array}$ & $\begin{array}{c}\text { MOR } \\
(\mathbf{M P a})\end{array}$ & $\begin{array}{c}\text { IB } \\
(\mathbf{M P a})\end{array}$ \\
\hline T1 $(100 \mathrm{~B} / 0 \mathrm{~T})$ & 0.79 & 1592 & 19.57 & 1.77 \\
$\mathrm{~T} 2(50 \mathrm{~B} / 50 \mathrm{~T})$ & 0.81 & 1779 & 25.19 & 1.59 \\
$\mathrm{~T} 3(33 \mathrm{~B} / 67 \mathrm{~T})$ & 0.76 & 1732 & 22.99 & 2.07 \\
T4 (0B/100T) & 0.80 & 1851 & 22.96 & 2.65 \\
VC (\%) & {$[3.42 ; 9.84]$} & {$[7.87 ; 20.11]$} & {$[7.07 ; 13.69]$} & {$[9.40 ; 25.14]$} \\
\hline Treatment & $\mathbf{F S H}$ & $\mathbf{E S H}$ & $\mathbf{T S 2}$ & $\mathbf{T S 2 4}$ \\
\hline T1 (100B/0T) & $\mathbf{( N )}$ & $\mathbf{( N )}$ & $\mathbf{( \% )}$ & $\mathbf{( \% )}$ \\
T2 $(50 \mathrm{~B} / 50 \mathrm{~T})$ & 832 & 930 & 4.84 & 12.81 \\
T3 (33B/67T) & 808 & 1248 & 5.04 & 12.95 \\
T4 (0B/100T) & 1003 & 1615 & 5.93 & 13.53 \\
VC (\%) & {$[13.44 ; 18.90]$} & {$[6.75 ; 10.98]$} & {$[13.93 ; 23.17]$} & {$[6.74 ; 20.06]$} \\
\hline
\end{tabular}

194 Silva, V. U. da; Aquino, V. B. de M.; Ruthes, H. C.; Christoforo, A. L.; Lahr, F. A. R. 
Graphs illustrating the mean values and variance coefficients of the physical and mechanical properties are shown in Figure 3 and Figure 4 respectively. The Tukey test was applied to investigate the influence of the wood from the branches (\%TB), following the disposed on Table 1, in the properties of the particleboards. A represents the highest mean value and $\mathrm{B}$ the second highest mean value; equal letters represent means that were statistically equivalents.

From Figure 3 it can be observed that density and TS24 weren't affect as much as TS2 by the percentage of wood from the branches in its composition where the lowest value occurs when there is no wood from the trunk. From Figure 4 where the mechanical properties were verified, only IB and FSH were significantly affected by the variation of the composition, and the treatment with no wood from the branches (T4) performed better.

It is interesting to notice that the properties of the particleboards made entirely of wood from the branches (T1) have a smaller variance than the opposite case (T4), which indicates that there is more statistical stability in the properties when working with particles from the branches, meaning that their results are more predictable, containing fragile material, with green wood, weakening the particleboard.

Table 4 shows the requirements of the national standard NBR 14810 (ABNT, 2018) and the normative documents from other countries such as A 208.1 (AMERICAN..., 2009), EN 312 (EUROPEAN..., 2003) and CS 236 (COMMERCIAL..., 1968). Table 5 shows the results of similar studies.

From the comparison between Table 3 and Table 4 it is possible to notice that MOR and IB values obtained in this study were high above the threshold established by the referenced normative documents, but the other properties had values that fluctuated close to the threshold. This means that not all the particleboards produced fit the requirements, but it also indicates that it is possible to refine the production process to improve the final product and try to make it comply with at least one of the standards.

Since there were no previous studies regarding the production of particleboards with mahogany wood residues, the results of this study were put side by side with those of similar researches that used wood from branches or industrial timber residue to produce particleboards, disposed on Table 5.

Figure 3 - Mean values and variance coefficients of physical properties
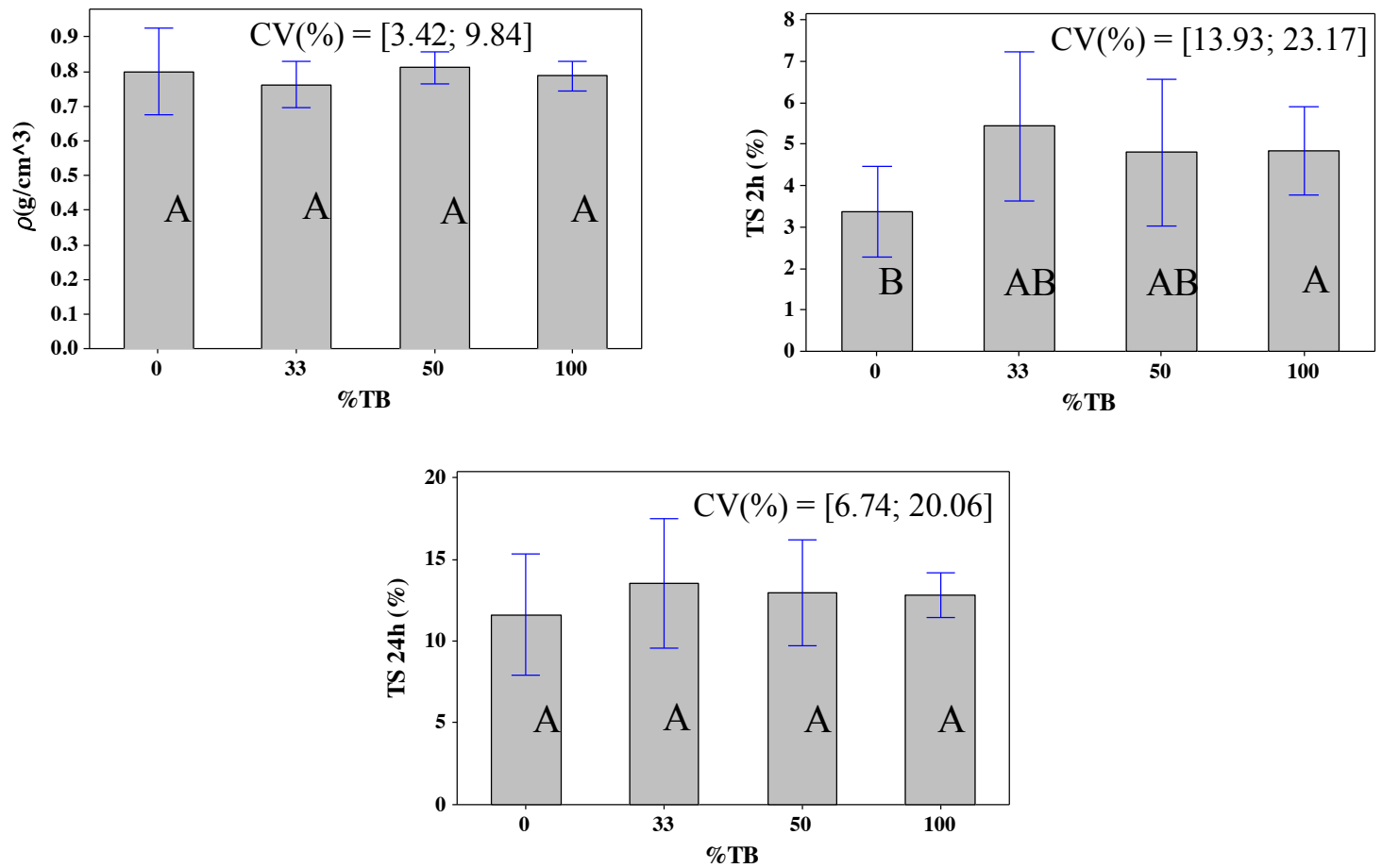
Figure 4 - Mean values and variance coefficients of mechanical properties
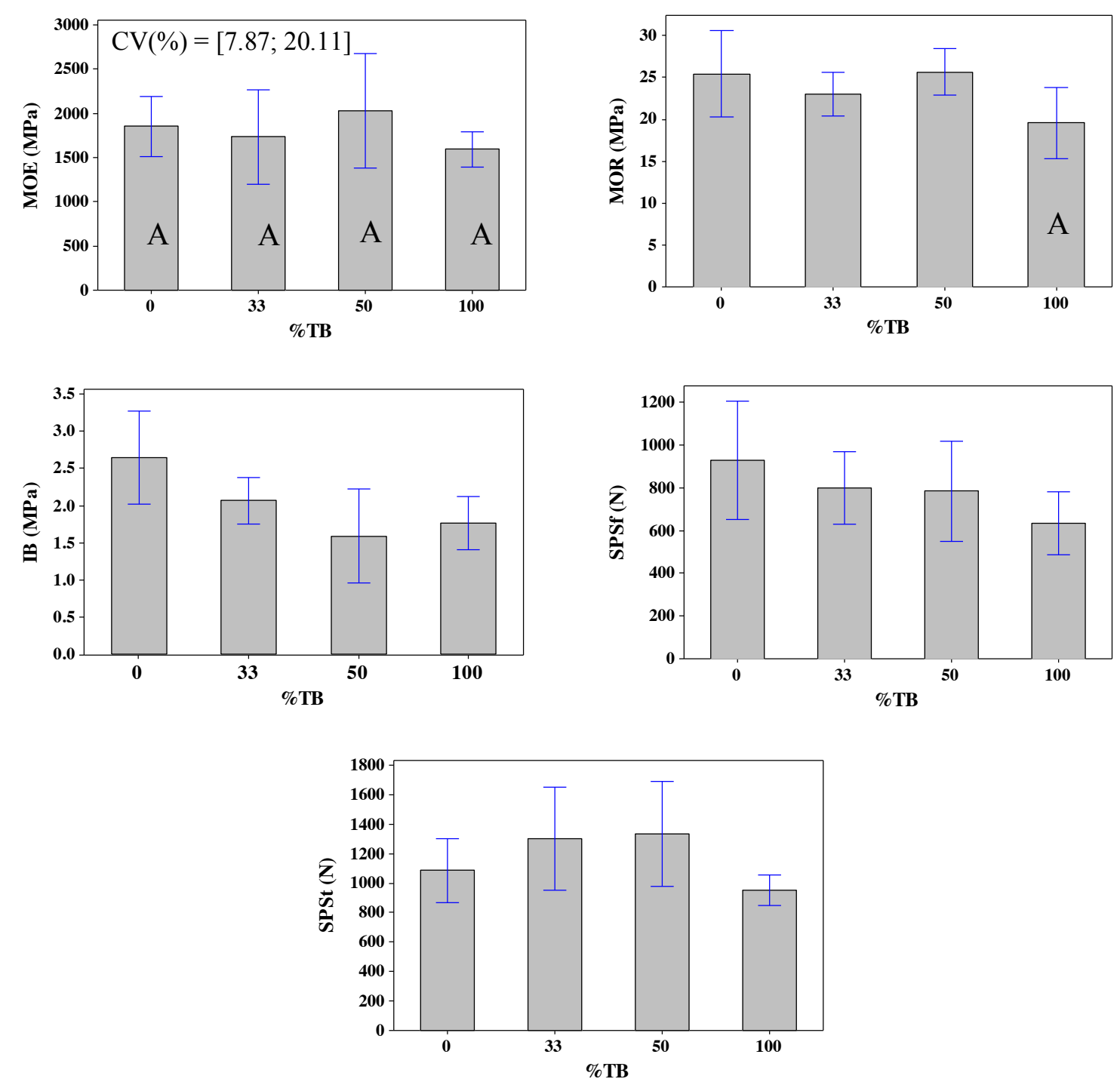

Table 4 - Main properties listed in the normative requirements

\begin{tabular}{l|c|c|c|c|c|c}
\hline \multicolumn{1}{c|}{ Standard } & $\begin{array}{c}\text { MOE } \\
(\mathbf{M P a})\end{array}$ & $\begin{array}{c}\text { MOR } \\
(\mathbf{M P a})\end{array}$ & $\begin{array}{c}\text { IB } \\
(\mathbf{M P a})\end{array}$ & $\begin{array}{c}\text { TS24 } \\
(\boldsymbol{\%})\end{array}$ & $\begin{array}{c}\text { FSH } \\
(\mathbf{N})\end{array}$ & $\begin{array}{c}\text { ESH } \\
(\mathbf{N})\end{array}$ \\
\hline NBR 14810* (ABNT, 2018) & 1800 & 11 & 0.4 & 18 & - & - \\
A 208.1** (AMERICAN.., 2009) & 1725 & 11 & 0.4 & - & - & - \\
EN 312* (EUROPEAN..., 2003) & 1800 & 13 & 0.4 & 18 & - & - \\
CS 236*** (COMMERCIAL..., 1968) & 1750 & 12.6 & 0.4 & - & 1020 & 725 \\
\hline
\end{tabular}

Note: *values corresponding to P2 grade; **values corresponding to $\mathrm{M}-1$ grade; and ${ }^{* * *}$ values corresponding to $2 \mathrm{~B} 1$ grade.

Table 5 - Results of literature studies

\begin{tabular}{l|c|c|c|c|c}
\hline \multicolumn{1}{c|}{ Study } & $\begin{array}{c}\text { Density } \\
\left(\mathbf{g} / \mathbf{c m}^{\mathbf{3}}\right)\end{array}$ & $\begin{array}{c}\text { MOE } \\
(\mathbf{M P a})\end{array}$ & $\begin{array}{c}\text { MOR } \\
(\mathbf{M P a})\end{array}$ & $\begin{array}{c}\text { IB } \\
(\mathbf{M P a})\end{array}$ & $\begin{array}{c}\text { TS24 } \\
(\boldsymbol{\%})\end{array}$ \\
\hline Sam-Brew and Smith (2017) & 0.66 & 3290 & 18.24 & 1.10 & 16.67 \\
Sugahara et al. (2019) & 0.88 & 3020 & 31.00 & 2.52 & - \\
Yano et al. (2020) & 0.71 & 2034 & 7.40 & 1.00 & 24.27 \\
Silva et al. (2021) & 0.89 & 1395 & 15.50 & 1.02 & 17.79 \\
\hline
\end{tabular}


The studies of Sam-Brew and Smith (2017) using flax shive and polymeric diphenil methane diisocyanite at $5 \%$ of flax shive mass particles, Sugahara et al. (2019), using industrial timber residue from Eucalyptus $(60 \%)$ and sugarcane bagasse $(40 \%)$ and castor oil based bicomponent polyurethane resin $(10 \%$ of wood mass particles), Yano et al. (2020), using tropical hardwood industrial residues (50\%), sugarcane bagasse $(50 \%)$ and castor oil based bicomponent polyurethane resin (10\% of wood mass particles) and Silva et al. (2021), using barks and branches of Eucalyptus (50\%) and sugarcane bagasse (50\%) and castor oil based bicomponent polyurethane resin (10\% of wood mass particles) showed values close to the obtained in this research, with some particleboards results being classified for structural and non-structural use according Brazilian Standard (ABNT, 2018) and American Standard (AMERICAN..., 2009).

The results in the present research indicates the use of particleboards made of mahogany branches and trunks for non-structural purpose, such acoustic absorption and thermal insulation on buildings, being an alternative for reuse of such waste on sawmill industries.

\section{Conclusions}

The main conclusion derived from the experiment was the feasibility of particleboard production using mahogany wood residues as base material, and that the presence of wood from the branches in the composition of the boards does not affect significantly most of the properties observed, which means that the sawmill residues and the branches prevenient of the pruning process can be used together as a compound in particleboard production.

\section{Referências}

ADINUGROHO, W. C.; SIDIYASA, K. Model pendugaan biomassa pohon mahoni (Swietenia macrophylla King) di atas permukaan tanah. Jurnal Penelitian Hutan dan Konservasi Alam, v. 3, n. 1, p. 103-117, 2006.

AMERICAN NACIONAL STANDARDS INSTITUT. A 208.1: particleboards physical \& mechanical properties requirements. Gaithersburg, 2009.

ASSOCIAÇÃO BRASILEIRA DE NORMAS TÉCNICAS. NBR 14810: chapas de madeira aglomerada. Rio de Janeiro, 2018.

BERTOLINI, M. S. et al. Painéis de partículas provenientes de rejeitos de Pinus sp. tratado com preservante cca e resina derivada de biomassa. Revista Árvore, v. 38, n. 2, p. 339-346, abr. 2014.

BLUNDELL, A. G. A review of the CITES listing of big-leaf mahogany. Oryx, v. 38, n. 1, p. 84-90, 2004.

BLUNDELL, A.; GULLISON, R. E. Poor regulatory capacity limits the ability of science to influence the management of mahogany. Forest Policy and Economics, v. 5, n. 4, p. 395-405, 2003.

BRASIL. Lei 12.305, que institui a Política Nacional de Resíduos Sólidos e dá outras providências. 2010. Disponível em: http://www.planalto.gov.br/ccivil_03/_Ato2007-2010/2010/Lei/L12305.htm. Acesso em: 7 mar. 2021.

COMMERCIAL STANDARD. CS 236: material formed wood particleboard. 1968.

EUROPEAN COMITTEE FOR STANDARDIZATION. EN 312: particleboards: specifications. Lisboa, 2003.

FERRO, F. S. et al. Effect of alternative wood species and first thinning wood on oriented strand board performance. Advances in Materials Science and Engineering, v. 2018, art. 4603710, 2018.

FERRO, F. S. et al. Influence of proportion polyol/pre-polymer castor-oil resin components in static bending properties of particleboards produced with Pinus sp. Advanced Materials Research, v. 884-885, p. 667$670,2014$.

FOREST STEWARDSHIP COUNCIL. Welcome Back, Mahogany! 2016. Disponível em: https://fsc.org/en/newsfeed/welcome-back-mahogany. Acesso em: 7 mar. 2021.

GERWING, J. J.; JOHNS, J. S.; VIDAL, E. Reducing waste during logging and log processing: Forest conservation in eastern Amazonia. Unasylva, v. 187, p. 17-25, 1996. 
GROGAN, J. et al. What loggers leave behind: Impacts on big-leaf mahogany (Swietenia macrophylla) commercial populations and potential for post-logging recovery in the Brazilian Amazon. Forest Ecology and Management, v. 255, n. 2, p. 269-281, 2008.

LAMB, F. B. Mahogany of tropical America: its ecology and management. Ann Arbor: University of Michigan Press, 1966.

MACEDO, L. B. et al. Paineis híbridos de lâminas e partículas de madeira para uso estrutural. Ambiente Construído, Porto Alegre, v. 19, n. 3, p. 15-23, jul./set. 2019.

RIVELA, B. et al. Life cycle inventory of particleboard: A case study in the wood sector. International Journal of Life Cycle Assessment, v. 11, n. 2, p. 106-113, 2006.

RIZZINI, C. T. Árvores e madeiras úteis do Brasil: manual de dendrologia brasileira. 2 ed. ed. São Paulo: Edgard Blucher, 1990.

SAM-BREW, S.; SMITH, G. D. Flax shive and hemp hurd residues as alternative raw material for particleboard production. BioResources, v. 12, n. 3, p. 5715-5735, 2017.

SASAKI, N. et al. Sustainable management of tropical forests can reduce carbon emissions and stabilize timber production. Frontiers in Environmental Science, v. 4, art. 50, 2016.

SILVA, S. A. M. et al. Medium Density Particleboard (MDF) produced with Pinus caribaea fibers and castor oil based Polyurethane resin. Advanced Materials Research, p. 13-16, 2014.

SILVA, S. A. M. et al. Use of residues from the cellulose industry and sugarcane bagasse in particleboards. Engenharia Agrícola, v. 41, n. 1, p. 107-111, fev. 2021.

SUGAHARA, E. S. et al. High-density particleboard made from agro-industrial waste and different adhesives. BioResources, v. 14, n. 2018, p. 5162-5170, 2019.

VERÍSSIMO, A. et al. Extraction of a high-value natural resource in Amazonia: the case of mahogany. Forest Ecology and Management, v. 72, n. 1, p. 39-60, 1995.

YANO, B. B. R. et al. Use of sugarcane bagasse and industrial timber residue in particleboard production. BioResources, v. 15, n. 3, p. 4753-4762, 2020.

\section{Agradecimentos}

Authors would like to thank: Wood and Timber Structures Laboratory (LaMEM), Department of Structural Engineering, its technicians and employees; Department of Materials Engineering; São Carlos School of Engineering (EESC) and the University of São Paulo (USP) for everything that contributed to this project. In the same way the authors would like to thank the Coordenação de Aperfeiçoamento de Pessoal do Nível Superior - Brazil (CAPES) and the Conselho Nacional de Desenvolvimento Científico e Tecnológico Brazil (CNPq) for the financial support.

198 Silva, V. U. da; Aquino, V. B. de M.; Ruthes, H. C.; Christoforo, A. L.; Lahr, F. A. R. 
Vitor Uemura da Silva

Structural Engineering Department | São Carlos Engineering School | University of São Paulo | Av. Trabalhador São Carlense, 400 | São Carlos - SP - Brasil | CEP 13566-590 | Tel.: (16) 3373-8206 | E-mail: japauemura@gmail.com

Vinicius Borges de Moura Aquino

Civil Engineering Departament | Federal University of South and Southeast of Pará | Rua Geraldo Ramalho, 33 | Santana do Araguaia - PA - Brasil | CEP 68560-000 | Tel.: (94) 2101-5936 | E-mail: aquino.vini@hotmail.com

\section{Heloiza Candeia Ruthes}

Civil Engineering Department | Federal University of São Carlos | Rod. Washington Luis, km 235 | São Carlos - SP - Brasil | CEP 13565-905 | Tel.: (16) 3351-8262 | E-mail: heloruthes@gmail.com

\section{André Luis Christoforo}

Civil Engineering Department | Federal University of São Carlos | E-mail: christoforoal@yahoo.com.br

\section{Francisco Antonio Rocco Lahr}

Structural Engineering Department | São Carlos Engineering School | University of São Paulo | E-mail: frocco@sc.usp.br

\section{Ambiente Construído}

Revista da Associação Nacional de Tecnologia do Ambiente Construído

Av. Osvaldo Aranha, $99-3^{\circ}$ andar, Centro

Porto Alegre - RS - Brasil

$$
\text { CEP } 90035-190
$$

Telefone: +55 (51) 3308-4084

www.seer.ufrgs.br/ambienteconstruido www.scielo.br/ac

E-mail: ambienteconstruido@ufrgs.br 